\title{
Rui Barbosa - Aspectos de sua Vida e de sua Obra*.
}

\author{
Nicolau Nazo \\ Professor Emérito da Faculdade de Direito \\ da Universidade de são Paulo.
}

Inicia-se hoje o ciclo de conferências sôbre a vida e obra de Ruy Barbosa.

O momento não poderia ser mais oportuno. A uma condigna comemoração da data natalícia dos cursos juridicos em São Paulo e Olinda, alia-se a circunstância de cultuarmos a memória de uma das figuras do mais impressionante relêvo que a nossa nacionalidade produziu e que uma pequena história, como lhe chamou Wílson Martins, em que "o que mais falta é justamente o senso histórico", procura situá-la "num plano completamente diverso daquele em que se faz e perpetua a história ( $O$ Estado de São Paulo, de 24 de julho de 1965).

Em tema de tal magnitude, nunca se deve perder de vista a observação de Santiago Dantas de que

“ .a lição de um grande homem não atinge a plenitude da eficácia, senão quando, por um ato de raciocínio, o excluirmos de nossa objetividade. para o contemplarmos na objetividade de sua posição histórica, pensando e agindo como pessoa

* Conferênc:a proferida a 11/8/1965, no Salão Nobre da Faculdade de Direito da Universidade de São Paulo, primeira dentro do ciclo programado pela Congregação dos Professôres daquela casa de ensino, em defesa da obra de Ruy Barbosa. 
dramática da sociedade em que viveu. Só então se desprende dêle, livre para sempre do perigo de envelhecer, o modêlo que nos pôde legar, o sentido universal, que nele pressentimos, mas não formulávamos.

Êsse sentido, não o encontraremos em RuY BARBosA, enquanto nos limitarmos a lhe estudar a ideologia, sem a compreensão das realidades profundas a que serviu, e de que suas idéias, como mais tarde sua legenda, foram um instrumento de defesa e de realização".

(Dois momentos de Rui Barbosa, págs. 11-12).

Confundindo-se a vida de Ruy com a história da própria nacionalidade, constituiria inconcebivel contrasenso deslocá-la da época e do meio em que viveu para analisar fatos e gestos que não encontrariam ressonância em outros momentos históricos, dominados por nova sensibilidade política, artística, literária ou econômica.

$\mathrm{Na}$ análise de um homem e principalmente de um grande homem que com ímpar genialidade se desdobrava em jurista, filólogo, humanista, orador, jornalista, escritor, em suma, artista; em político, diplomata, propagandista, construtor de um regime, em uma palavra, o estadista, todos êsses predicados nele se reuniam, como observa Joño Mangabeira, não teria sentido a unilateralidade de julgamento, na perquirição de nugas ou contradições. E tanto não tem sentido essa unilateralidade de julgamento quanto é necessário não perder de vista a época de transição em que as complexas atividades de Ruy se desenvolveram.

A transição não se verificou apenas em determinado dominio da vida da sociedade brasileira. Ao contrário, estendeu-se à política em que o país passou da monarquia à república; à literatura, em que ao romantismo das últimas fases, se substituem e se desenvolvem o realismo e o parnasianismo; à renovação da sociedade, em que surge "uma classe, que contrapõe sua mentalidade pequeno- 
burguesa, seu espírito de precavida iniciativa, à mentalidade feudalista, própria da grande classe agrária", (SANTIAGO DANTAS; $o p$. cit.); à política financeira determinada pela expansão do meio circulante como um recurso de financiamento à produção. A própria forma de expressão literária não representou fenômeno isolado nesse período, pois ao cuidado da forma se junta a necessidade de uma linguagem cada vez mais apurada. No domínio do Direito Internacional Público, proclama-se a igualdade das nações em face do Direito e a questão social deveria encontrar no Título XIII do Tratado de Versalhes a afirmação de princípios que concluíram pela Organização Internacional do Trabalho, os quais já tiveram um paladino em RuY Barbosa, como com grande brilho demonstrou Ernesto LEME em monografia dedicada a êsse assunto.

Em todos êsses momentos, da mesma forma como fizera quando estudante em São Paulo (período de que Antônio GontiJo de Carvalho traçou magistral panorama), RuY não se alheou da realidade. Ao contrário, apesar de seu idealismo e talvez devido a isso mesmo, não houve problema que afetasse a nacionalidade ou que o interêsse público estivesse em jôgo que não merecessem a sua esclarecida intervenção, pela palavra ou pela ação.

Disse-o êle mesmo, no discurso com que respondeu a Constâncro Alves, por ocasião do seu jubileu literário, realçando a agitada vida política, em oposição ao recato e à quietude dos estudos:

"Mas qual é, na minha existência, o ato da sua consagração essencial às letras? Onde o trabalho, que assegure à minha vida, o caráter de predominante ou eminentemente literário? Não conheço" e, depois de enumerar alguns dos muitos trabalhos com que enriqueceu a nossa literatura, acrescentou:

"Que mais? Não sei, eu de pronto não me lembro. Tudo o mais é política, é administração, é direito, são questões morais, religiosas, questões sociais, projetos, reformas, 
organizações legislativas. Tudo o mais demonstra que êsses cinqüenta anos me não correram na contemplação do belo, nos laboratórios da arte, no culto das letras pelas letras. Tudo o mais está evidenciando que a minha vida Łôda se desdobra nos comícios e nos trikunais, na imprensa militante, ou na tribuna popular, em eposições ou revolucões, em combate a regimes estabelecidos e organização de novos regimes. O que ela tem sido, a datar do seu primeiro dia, a datar do brinde político a José Bonifácio, em 13 de agôsto de 1868, é uma vida inteira de ações, peleja ou apostolado".

Fôra, na verdade, um autêntico apostolado de que êle mesmo, a seguir, descreve as etapas de maior significação, para concluir com êstes periodos que não resisto à tentação de ler, porque condensam, sintetizam, em tôda a sua plenitude, as lutas que êle sustentou:

“Os órgãos de publicidade, que redigi eram, todos êles, de política militante; os livros que escrevi, trabalhos de atividade pugnaz; as situações, em que me distingui, situações de energia of ensiva ou defensiva. Propugnei, ou adversei governos, golpeei ou escudei instituições, abalei até à morte um regime, contra prepotências e abusos, contra oligarcas e tiranos. Ensinei, com a doutrina e com o exemplo, mas ainda mais com o exemplo que com a doutrina, o culto e a prática da legalidade; as normas e o uso da resistência constitucional, o desprêzo e o horror da opressão, o valor e a eficiência de justiça, o amor e o exercício da liberdade.

Uma existência, vivida nos campos de batalha, tecida assim, tôda ela dos fios de ação combatente, não se desnatura de sua resistência, não se desintegra dos seus elementos orgânicos, para se apresentar, desvestida e transmudada, naquilo que ela tem de menos, na mera existência de um homem de letras. Como quer que se encare, boa ou má, é a de um missionário, é a de um soldado, é a de um construtor". 
Nenhum excesso ou exagêro nessas palavras, que bem refletem a forte têmpera de lutador, que havia em RuY BARBOSA.

$\mathrm{E}$ mais do que a forte têmpera de lutador o que impressiona e se impõe à admiração dos pósteros é a obra de edificação, de construção que realizou numa fase de instabilidade política, econômica e social, decorrente justamente da passagem de um regime para outro.

A êsse propósito, paga a pena assinalar o depoimento de político que lhe não dedicava grande afeição, DunscheE DE Abranches, que no prefácio de Atas e Atos do Govêrno Provisório escreve: "Na primeira semana, após a proclamação da República, só um cérebro pensou e agiu - Ruy Barbosa".

Não foi, no entanto, sòmente na primeira semana. Nos quatorze meses que estêve no govêrno provisório, mais de metade dos decretos coletivos são de sua inspiração e do seu punho.

Vice-chefe do govêrno provisório, ministro da Fazenda e interino da Justiça, principal artífice da Constituição, estabeleceu os fundamentos da ordem jurídica do novo regime e dirigiu as finanças, apoiado num plano que Joaquim Murtinho, em relatório que dizia "conter verdades profundas e amargas", adotava uma das medidas principais daquele plano e publicava o quadro das emissões, no qual se patenteava que fôra Rui Barbosa quem menos emitira, e assim mesmo em emissão bancaria $e$ sôbre lastro".

Já muito se escreveu sôbre o Plano Financeiro, constituindo o Relatório um repositório de sugestões e ensinamentos que ainda hoje possuem a maior atualidade, e que aliás mereceu de Cincinato Braga o elogio de "Quanto mais estudo o Plano Financeiro do Govêrno Provisório, mais me convenço de que a ação de Rur foi genial. A 
verdade, porém, é que Rui tanto como na elaboração do Plano Financeiro", foi refletida ou espontâneamente, no dizer de Santiago Dantas, o ideólogo de uma reforma da sociedade. Não de uma reforma ocasionada pela brusca avulsão de certos valores, pela eclosão revolucionária de novas formas de vida, mas de uma reforma iniciada difusamente nos últimos decênios da monarquia, que mergulhava nos primórdios da nacionalidade suas terminações radiculares e que encontrou no advento do regime Republicano o momento essencial de sua fixação de rumo" e essa reforma foi chamada por Santiago Dantas, dentro dos limites que estabeleceu: "a ascensão da classe média"

Evidentemente, não de uma classe média tal como a entendemos presentemente, mas constituindo "uma nova camada social que se avoluma nos anos do ocaso da Monarquia, traz consigo um destino, um imperativo vital que se levanta contra as formas obsoletas da sociedade que a contém. Industriais e negociantes - a classe média civil - ligada ao Exército nacional - a classe média militar — podem ter entre si discordâncias de idéias, antagonismo, mas estão ligados pelo mesmo imperativo de alteração dos quadros vigentes e por isso geram e executam a República.

Na nova ordem que se instaurou, uma personalidade lhes resume o espírito e encarna o método: o Ministro da Fazenda do Govêrno provisório: Rú Barbosa.

Outra ambição não tivera nos agitados dias que se sucederam à proclamação da República senão a consolidação e o fortalecimento do regime. A melhor prova do idealismo de seus propósitos têmo-la na recusa ao pedido de Deodoro de lhe entregar a chefia do Govêrno. Data de 6 de maio de 1890 a carta de Deodoro, concebida nos seguintes termos:

"Ilmo. amigo sr. dr. Rui Barbosa - Pràticamente para mim, é-me impossível o alto cargo de que fui investido - 
o de chefe do govêrno provisório - porquanto nem tenho. a paciência de Jó, nem desejo os martirios de Jesus Cristo: se por sermos filhos do pecado, temos que pagar neste mundo os êrros de origem, contudo nos ficou a faculdade de evitar sofrimentos e assim não tendo eu a louca pretensão de querer me aproximar de Jó, nem de Jesus. Cristo, me julgo sem fôrças para continuar em tal cargo. A V.Exa., portanto, que é o primeiro vice-chefe do govêrno, entrego os poderes que me foram conferidos e retiro-me para o meu quartel, onde me achará quando, em matéria de minha profissão, se precisar do velho soldado. Com estima e muita consideração, sou de V.Exa. muito agradecido. Deodoro".

Ruı, que, por três vêzes, no mês de janeiro e outra a 6 de março daquele ano havia solicitado exoneração. do cargo de ministro, não se envaideceu, nem se deixou fascinar pelo pedido de Deoboro. Ao contrário, declarou peremptòriamente que não aceitava a sucessão, Deodoro acabou cedendo e Rui continuou sendo, como dizia Quintino Bocaiuva, o para raios do govêrno provisório, visto como arcava com as eonseqüências de duas revoluções, uma, de caráter social, a abolição e outra, de natureza política, a República.

Não fôssem a ascendência que Ruı exercia sôbre Deonoro e o prestígio que conquistara entre seus companheiros. de ministério e, por certo, não simplesmente dramáticos, mas trágicos teriam sido os primeiros tempos da República. Haja vista, nesse sentido, a relutância do Chefe do Govêrno em assinar o projeto de Constituição, tal como ficara redigido após a profunda revisão a que RuI submetera o que fora elaborado pela comissão presidida por Saldanha Marinho. Deodoro não se mostrara adatado à nova forma de govêrno, pois, parecia-lhe necessário ter poderes para dissolver o Congresso. Refere a história que quando deparou com o caso da responsabilidade do chefe 
do Estado, passou a pena, declarando resoluto que nem Deus Padre teria fôrça para obrigá-lo a assinar aquêle diploma. Depois de grande trabalho, Rui conseguiu que ele cedesse. E acrescenta Mario de Lima Barbosa: "E no fim, quando chegou o momento de assinar o projeto, èle disse, com ar de troça, para Rui: "Pois bem; o senhor quer que eu assine a Constituição, como está feita, mas talvez como aconteceu com o Antonio Carlos, o senhor ainda terá de sair desse Congresso, inclinando-se diante da majestade de um canhão", e Rur teria retrucado incontinenti: "Confio muito no patriotismo de V.Exa. e peço licença para dizer-lhe que não me arreceio de que isso aconteça jamais". "Ambos eram sinceros", como assevera Viana Filho. "Rui a bater-se pela construção de um regime semelhante ao da América do Norte. Deodoro sempre cioso das prerrogativas da sua autoridade".

É de ontem ainda a fase de renovação de valores em que surge Ruı com a "Réplica", atraindo a atenção dos inteletuais para a redação do Código Civil e que sucede à publicação de A Ilusão Americana, de Eduardo Prado e às Cartas de Inglaterra, sem falarmos nas obras de Joaguim Nabuco, de Graça Aranha e Euclides da Cunha. O romantismo vai cedendo logar ao parnasianismo, representado pela tríade constituída por Olavo Bilac, Alberto de Oliveira e Raimundo Corrêa.

É dessa época o comentário de Joaquim Nabuco sôbre o estilo de Rui, escrevendo: "Rui Barbosa hoje, a mais poderosa máquina cerebral do nosso país, que pelo número de rotações e fôrça de vibração faz lembrar o maquinismo que impele, através das ondas, os grandes transatlânticos, leva 20 anos a tirar minério do seu talento, a endurecer e temperar o aço admirável que é agora o seu estilo".

Não há quem desconheça o papel que a Réplica representou na evolução da linguagem em nosso país. Procurase aperfeiçoar a forma, recorre-se à lição dos clássicos, 
us nossos escritores não insistem mais na preocupaçio daquilo que se denominava "dialeto brasileiro", contra o qual se lança Ruı com o seu carcasmo, chamando-lhe de "surrão amplo onde cabem, desde que o inventaram para sossêgo dos que não sabem a sua língua, tôdas as escórias da preguiça, da ignorância e do mau gòsto, rótulo americano daquilo que o grande escritor lusitano tratara pelo nome angolês". O escritor lusitano era Antônio Castillo. Não fôra a Réplica, em verdade, não poderiamos hoje também homenagear o grande mestre da língua que foi Ernesto Carneiro Ribeiro, que, além da Réplica, devia oferecer aos que querem realmente conhecer a língua os excelentes Serões Gramaticais.

Não é fácil no angustioso lapso de tempo que é concedido a quem deve apenas iniciar uma série de conferências sôbre Rur Barbosa mencionar, mesmo que superficialmente, as múltiplas e complexas atividades a que o seu gênio imprimiu o sêlo de sua personalidade.

A produção intelectual de Rui é verdadeiramente ciclópica, tanto como a sua ação, que não se restringia à simples expressão verbal ou escrita.

Não caberia, pois, não só pelo limitado espaço de tempo de que dispomos, mas principalmente pelo fato de, em se tratando de temas que deverão ser desenvolvidos por eminentes mestres desta Faculdade, em sucessivas conferências, não ter sentido dizer algo, mesmo perfuntòriamente, do jurista, do filólogo, do orador ou do jornalista, do escritor ou do político, do diplomata ou do construtor de um regime, de um estadista, enfim, pois todos êsses predicados nele se reunem.

A Faculdade de Direito da Universidade de São Paulo, com efeito, não poderia primar pelo silêncio, que poderia parecer conivência diante da publicação do livro de RaYmunde Magalhães Jr.: Rui - O homem e o mito e dai a 
resolução tomada em reunião da Congregação a 11 de fevereiro dêste ano, condenando o referido livro, de alertar a mocidade acadêmica contra "idéias, que instilam veneno, amesquinham glórias nacionais e até ameaçam abalar a estrutura de nossa sociedade. A fim de orientar os môços no culto de nossas gloriosas tradições, foi cometido a um grupo de professôres o encargo de proferirem conferências, restabelecendo a verdade e rechassando as aleivosias lançadas por Magalhães Júnior sôbre a vida e a obra de Ruı".

Limitamos a nossa tarefa apenas em acentuar o papel que mais convém numa comemoração como a de hoje, qual seja, por uma feliz coincidência, a perfeita adequação dos conceitos emitidos recentemente pelo Santo Padre Paulo vi, relativamente ao advogado e que tiveram em Rur a mais completa expressão.

Nele se reuniam as qualidades de sacrifício, de independência, de combatividade e de altivez, que o tornaram o paradigma de nossa profissão, não fazendo - como podia proclamar na Oração aos Moços — "da banca balcão ou da ciência mercatura", "não sendo baixo com os grandes, nem arrogante com os miseráveis", "servindo aos opulentos com altivez e aos indigentes com caridade", amando "a pátria, estremecendo o próximo, guardando fé em Deus, na verdade e no bem"

Dirigindo-se aos membros do Conselho da União Internacional dos Advogados a 14 de maio dêste ano, dizia Paulo vi:

"O advogado assiste, aconselha, defende. Mas, para assim fazer, deve êle conhecer. Manifesta-se, aqui, outro aspecto de sua personalidade: um homem à procura da verdade. Verdade dos fatos, para estabelecer a defesa num terreno sólido; verdade das leis, cujo conhecimento perfeito se torna um dever para sua consciência profis- 
sional; verdade das almas, sobretudo, quando delas recolhe, tão comumente, os mais intimos segredos. Ninguém talvez, afora o sacerdote, conhece melhor que o advogacio a vida humana sob os mais variados aspectos, os mais dramáticos, os mais dolorosos, os mais viciosos, por vêzes, mas também, freqüentemente, os melhores. Não admira, portanto, que desde a antigüidade o advogado tenha sido o candidato mais indicado para as funções políticas e para os cargos públicos, por ser o mais capaz de exercêlos: era a homenagem espontâneamente prestada a seu valor humano, à sua capacidade, à sua experiência.

Se o advogado procura conhecer a verdade, não será para se tornar dela o avaro possuidor: será para divulgá-la, para fazê-la conhecida. É êle, por excelência, o homem da palavra. $O$ abuso que se faz da linguagem não é, a seu modo, como que uma homenagem à sua sublime função? Que poder tem a palavra para persuadir, para forçar o consentimento! Mas, também, que enorme responsabilidade tem aquêle que se utiliza dêste maravilhoso instrumento para colocá-lo ao serviço das paixões humanas!".

Não foi, acaso, Rư, em tôda a sua existência "um homem à procura da verdade, "verdade dos fatos, para estabelecer a defesa num terreno sólido", "verdade das leis", para cujo conhecimento perfeito realizou obra de beneditino, pacientemente semeando aquilo que colhera em horas seguidas de estudo, de meditação contínua, de assimilação e sedimentação dos conhecimentos adquiridos, "assistindo, aconselhando, defendendo", procurando conhecer a verdade, "para divulgá-la, para fazê-la conhecida?"

Não foi, acaso Rur, o homem da palavra, na mais elevada significação do termo, nas defesas que sustentou, 
nas páginas que escreveu e nas orações que proferiu no Supremo Tribunal Federaì, no Senado da República, em Haia e nas campanhas de civismo e de fé na democracia, em que a solidez da cultura vive irmanada à beleza da forma, e "lei e liberdade" constituíram para êle "a síntese de todos os mandamentos?" 